\title{
It's still a man's world
}

\section{Washington}

DESPITE four years of policy promoting balanced representation of women in clinical trials funded by the National Institutes of Health (NIH), many studies are still biased towards men, according to a General Accounting Office (GAO) report released last week. The issue was dramatized at the Sixth International Conference on AIDS (see page 753) when women protesters blocked traffic in central San Francisco to draw attention to the lack of clincial research on women who have AIDS.

"American women have been put at risk by medical research practice that fail to include women in research studies," said Patricia Schroeder (Democrat, Colorado) at a congressional hearing on the report last week. It is not known if aspirin can help to prevent coronary disease in women because the study establishing aspirin's value looked at 22,071 men, but no women, said Representative Olympia Snowe (Republican, Maine).

Iris Schneider, co-chair of the $\mathrm{NIH}$ advisory committee on women's health issues and assistant director for programme operations and planning at the National Cancer Institute, says that scientists sometimes avoid including women in their childbearing years because of concern that the treatment may affect fertility.

A fear that results will be distorted because of hormonal changes during menstruation has also biased some trials, Schneider says. "That is not something I can accept. Just because someone says that [women in clinical trials] presents a problem, that doesn't mean you can just walk away from it", she says. "There are clearly some specific cases in which there was a problem, but how large the problem is, no one knows". NIH is trying to obtain better statistics.

$\mathrm{GAO}$, in its investigation, reviewed 50 recent applications for NIH grants. Twenty per cent of the applications did not discuss the sex of the study population. Over one third of the proposals indicated that both sexes would be included but did not say in what proportions. Some of the studies using only men gave no explanation of why that choice had been made.

Although Schneider's NIH committee recommended publication of a policy on women in 1986, it was not published in the guide for outside researchers applying for NIH grants until 1989.

And NIH staff have yet to be trained about what the policy means and how it should be carried out, she says. Following two internal surveys that indicated that sexual imbalances existed in research within NIH, Schneider's committee sent new recommendations to former NIH director James Wyngaarden shortly before he left NIH last year. But it has yet to be acted on, she says.

The GAO report recommends that NIH train its staff and reviewers to watch for sexual bias in clinical trials. NIH acting director William Raub promised the congressional committee that NIH would follow GAO's advice. Schneider's committee will meet on 11 July to review the GAO report, perhaps making further suggestions. And the Congressional Caucus on Women's Issues will introduce legislation next month to bar the arbitrary exclusion of women from federally funded research and to create an office within NIH to coordinate women's health research and monitor other research for sexual equality.

Shigeko Segawa

\section{GLOBAL WARMING}

\section{Japan biding its time}

\section{Washington}

UNDER the impressive title "Action Program to Arrest Global Warming', Japan last week announced its first plan to restrict future greenhouse gas emissions. But the Council of Ministers' plan, which sets no targets beyond a vague commitment to stabilizing emissions by 2000 , may be far too sketchy to lessen criticism of Japan's global-warming policy.

Compared to the recent commitment by West Germany to cut carbon dioxide emissions by 25 per cent by 2005 , the Japanese plan appears remarkably noncommittal. The plan states that a "concrete target should be established after a full examination in order to achieve the stabilization of greenhouse gas emissions at their lowest level by the year 2000". But it does not specify what that level might be. Japanese government agencies are still debating how quickly carbon dioxide emission should be allowed to rise over the next decade, a decision that will help determine at what level to set the post2000 ceiling.

"According to the long energy vision by Ministry of International Trade and Industry (MITI), by the year 2000 , carbon dioxide emission will increase 16 per cent. But we are trying to keep carbon dioxide emissions as close to 1990 level as possible", says Kazuo Matsushita, an Environmental Agency officer. But although MITI officials commend the Environmental Agency for its optimistic vision, they are more pragmatic in outlook. MITI will not release a concrete plan until it is sure it can stick to it, and long negotiations between the Japanese ministries remain before even that is possible.

Shigeko Segawa
Latest deforestation figures

São Paulo

NEw figures for the extent of Amazonian deforestation were released by José Goldemberg, Secretary of State for Science and Technology, at a meeting of Latin American remote-sensing groups in Manaus last Sunday. According to the estimates prepared by Brazil's National Institute of Space Research (INPE) from 167 Landsat images taken during the latter half of 1989, the deforested area of the Legal Amazon has now reached 404,000 square kilometres (including ancient deforestation), up from the 1988 estimate of 343,975 square kilometres.

INPE officials refuse to issue the figures as percentages because of previous controversy over what land area constitutes the Amazon (see Nature 339, 531; 11 May 1990). If the Legal Amazon (an administrative definition) is taken as 'the Amazon', then 8.2 per cent may be calculated to have been destroyed since colonization began in the sixteenth century; if the area of rain forest alone is considered, then 10.9 per cent has been destroyed.

The measured increase in the area of destruction over the previous year is not all real, but is in part old destruction being measured for the first time. INPE sources estimate that about $30,000 \mathrm{sq} \mathrm{km}$ of destruction is new, putting rain forest destruction at 0.8 per cent a year. That figure is down from estimates from other remotesensing projects of $80,000 \mathrm{sq} \mathrm{km}$ of destruction for 1987 (2.1 per cent a year) and $48,000 \mathrm{sq} \mathrm{km}$ for 1988 (1.3 per cent).

\section{Monkey business}

Two Brazilian researchers have found a new species of monkey, but not deep in the Amazonian jungle where everyone might expect. The new species of lion tamarin was found in the Atlantic forest, in an island near the border of the states of Paramá and São Paulo. Such coastal regions are the most populated and extensively deforested in Brazil.

The discovery was reported in a workshop last week in Belo Horizonte and the new species christened Leontopithecus caissara. It joins three other known tamarin species, all of which are in risk of extinction as their habitats vanish.

The new tamarin was found by two researchers from a natural history museum in Curitiba, Paruná state capital, the Museu de História Natural Capão de Embuia. Vanessa Guerra Perssson and Maria Lúcia Lorini have been studying tamarins for about five years. They acted after reading a description written in $\mathbf{1 8 5 0}$ of monkeys living in the region. In February this year they were rewarded by a first sighting of five tamarins.

Ricardo Bonalume 